\title{
Policy Recommendations to Improve Trade Balance in Vietnam: An Empirical Study of Relationship between Exchange Rate and Trade Balance
}

\author{
Do Thi Man* \\ Lecturer at Faculty of Economic and Business Administration, Hong Duc University, No. 565 Quang Trung Street, \\ Dong Ve Ward, Thanh Hoa city, Vietnam \\ *Corresponding author: Mandt.hdu@gmail.com
}

\begin{abstract}
This research aims to analyze the effect of the real effective exchange rate on the trade balance in Vietnam using Vector Autor Regressive (VAR) model applying for quarterly data from 2000 to 2016. The tests of the impulse response function investigate that there exists a J-curve for Vietnam. The J-curve effect lasts about six quarters, which implies that the trade balance needs at least six quarters to improve after real depreciation of the domestic currency. The results of variance decomposition also show that real effective exchange rate plays the most critical role in the trade balance fluctuation since the fifth quarter till the long run, whereas, consumer price index has the second impact on the trade balance, foreign direct investment and gross domestic product seem not to much effect on the trade balance. Based on the results, the author gives some policy recommendations on improving the trade balance, including moving to a flexible exchange rate and coordinating between exchange rate policy and other macro policies.
\end{abstract}

Keywords: trade balance, REER, VAR, Vietnam

Cite This Article: Do Thi Man, "Policy Recommendations to Improve Trade Balance in Vietnam: An Empirical Study of Relationship between Exchange Rate and Trade Balance." Journal of Finance and Economics, vol. 6, no. 3 (2018): 75-86. doi: 10.12691/jfe-6-3-1.

\section{Introduction}

In an open economy, the exchange rate is significantly one of the most important macroeconomic variables and has considerable effects on the inflation rate, the international competitiveness on trade performance and investment, the financial stability, and the economic growth as a whole. In Vietnam, the exchange rate only became central to economic policy-making after the innovation in 1986. Since then, the exchange rate regime has gradually evolved from a system of multiple exchange rates to a single announced fixed rate, then to the current system incorporating a narrow adjustable band around the official rate. Through these changes, the exchange rate has been considered in a way that contributes to the achievement of national economic objectives in Vietnam. Studying the relationship between trade balance and the exchange rate is especially important for many developing economies, where trade balance faces deficit problem. The trade deficit is a matter of great concern to the countries around the world, due to its impact on the macroeconomic stability. As a world trade organization (WTO) member involved in the process of international economic integration, Vietnam has faced many challenges, including the problem of trade deficit. According to data from the General Statistics Office (GSO), the trade balance of Vietnam often falls into severe shortages. Therefore, when performing macroeconomic research, the researchers could not disregard this unsettled problem. Also, the behavior of the exchange rate, whether identified by exogenous or endogenous shocks, or by policy, is a widespread policy issue but still controversial in most countries.

In analysis impacts of exchange rate on macroeconomic variables, there are many theoretical and empirical studies concentrated on the relationship between exchange rate and the trade balance in Vietnam as well as in the world. Neither theoretical nor empirical research has established definitively whether a real depreciation of a country's domestic currency enhances its balance of trade or not, or even if exchange rates play a role in determining trade flows. This issue continues to be relevant to the understanding of the short-term and long-term relationship between those two variables using vector autoregressive model (VAR), then proposes policy recommendations for enhancement of the country's trade balance.

\section{Overview of Literature}

There have been many empirical studies on the shortterm and long-term relationship between trade balance and exchange rate. The following is a brief overview of the researchs that are provided for developed and emerging economies, as well as in Vietnam. Elif Guneren Genc and Oksana Kibritci Artar [1] determined the impact of exchange rates on imports and exports of economically 
developing countries. The study applied the methodology of the cointegration Panel Model for the period of 1985 2012. The results of this study show that there is cointegration between real effective exchange rate and export-import of emerging economies in the long run. In the total of 22 developing countries, Bolivia, Cameroon, Dominica, Gabon, and Mexico have both long-term relationship and short-term parameters are statistically significant. It is concluded that overall findings indicate that exchange rate effects support the expected results for the selected emerging countries. One more research of Tony Matlasedi, Richard Ilorah and Stephen Zhanje [2] which asserts the impact of the real effective exchange rate on South Africa's trade balance and whether the J-curve effect and the Marshal-Lerner condition are fulfilled in the South African economy. In this study, the bound test and Johansen cointegration test results show a long-term equilibrium relationship among trade balance, real effective exchange rate, gross domestic product (GDP), money supply, terms of trade and foreign reserves. The results show that the devaluation of the South African Rand (ZAR) improves the trade balance, in the long run, thus confirming the Marshal-Lerner condition. In the short term, a ZAR depreciation leads to a deterioration of the trade balance, thus establishing the J-curve effect for the RSA economy. Recently, Mohamed Nur Sharif and Ali Yassin Sheikh Ali [3] focused on the determinants of trade balance in Somalia. This study uses the Least squares method (OLS) under Eview 7.1 software for analysis with a sample period from 1970 to 2010 . The regression results show that foreign direct investment had negative impact on the trade balance in Somalia while other factors including exchange rate and inflation did not affect on the trade balance. As a result, the authors gave some recommendations for addressing the trade deficit in Somalia, such as keeping the policies stable to attract more investors and supporting export policies like investment incentive and taxes incentive.

Regarding the empirical studies of the relationship between trade balance and exchange rate in Vietnam from ten years ago and up, there are few quantitative studies on this relation. Those studies concentrate on the impact of exchange rates on exports in particular, the trade balance in general in which most of the studies in this field focus on the impact of exchange rates on the total export value over import value of the economy. Pham Hong Phuoc [4] approached the problem of exchange rate fluctuations affecting the trade balance in Vietnam. The author focused on the determinations of the real effective exchange rate (REER) market in Vietnam in 1999 - 2008. Accordingly, the study evaluates the impact of REER on import and export activities in Vietnam. By examining the regression model of the impact of the exchange rate on the exportimport ratio, the author showed that the exchange rate influences the import and export activities, besides, GDP still plays an essential role in import and export activities in Vietnam at that time. Nguyen Thi Hien [5] used the Engle-Granger Causality Test and the error correction model to test the relation between the exchange rate and the international balance of payments in Vietnam from 1999 to 2009. The study indicates that the overall balance of payments deficit pressure was triggered by a trade deficit in the current account. At the same time, the study also found a two-way interaction between the real exchange rate and the trade balance and specific latency effects. The two main groups of solutions proposed are (i) Solutions to improve exchange rates in the direction of international trade; (ii) Balance-of-payments improvement measures to help stabilize the exchange rate, improve exchange rate management by adjusting the current account and improving the capital balance. Dang Thi Huyen Anh [6] used the ordinary least squares method (OLS) in econometrics to describe the relationship between the real exchange rate and Vietnam's trade balance from 2002 to 2012 . The analysis shows that in many phases, it can be seen that the fluctuation of the real exchange rate has brought advantages for Vietnam's export and import of goods regarding price, trade improvement, and economic growth. Although the real exchange rate had an impact on import and export activity, the effect on the trade balance is not high, there were many periods which real exchange rate increased sharply, with a value greater than 1 , but the trade balance of Vietnam very little improved, even still in deficit. Nguyen Binh Duong, Tu Thuy Anh and Chu Thi Mai Phuong [7] examined the linkage between foreign direct investment (FDI) and trade balance in the case of Vietnam, including exports and imports. The primary results indicate that there is one-way causality linkage between exports and FDI. Concerning the linkage between FDI and imports, there are two ways causality linkage between these variables: import causes FDI and vice-versa in Granger's sense. Nguyen Thi Tuyet Nga [8] examined the role of exchange rates in the period of economic integration in Vietnam. She summarized the theory to further clarify the fundamentally theoretical problems of exchange rates and studied the experiences from countries such as China, Thailand, Korea, Malaysia and Mexico to study the lessons for Vietnam. When assessing the role of exchange rates during the integration period, she studied the exchange rate fluctuations in 1999-2011 and looked for issues in the current exchange rate. Accordingly, the study also proposed recommendations to adjust the exchange rate flexibility, maintaining a stable exchange rate based on real purchasing power of VND through the supply and demand relationship on the market. In the study of Hoang Khieu Van [9], a reduced-form VAR model is used to estimate the response of the trade balance to a positive shock to the real VND/USD exchange rate. For this purpose, he applied the definite restrictions based on the findings of Krugman, Obstfeld, and Melitz [10], and on the theory of the AA-DD model to estimate impulse response functions of the trade balance. He used a monthly dataset of four endogenous variables and two exogenous variables from January 1995 to December 2012. Overall, he found that there exists a J-curve for Vietnam, and its effect lasts for 11 months. Particularly, the worsening effect on the trade balance becomes most severe in the third and the fourth months. Nhat Mai Nguyen [11] used annual data from 1989 to 2013 and applied Ordinary Least Square (OLS) method to examine the effect of factors on the trade balance in Vietnam. The results show that Gross domestic product, Foreign direct investment, and oil price have positive impacts on trade balance while Government expenditure, Household expenditure, and industrial growth rate have adverse 
effects on the trade balance. The research of Nguyen Hai An [12] measures the effects of currency depreciation on inflation and trade balance in the case of Vietnam empirically. The author utilized the quarterly data from 2000 to 2012 for the Vector Autoregression (VAR) model to build the impulse response functions and variance decompositions of inflation and trade balance. The obtained results are remarkably consistent with economic principles in the theory review. The impulse response functions indicate that currency depreciation has a considerable negative impact on inflation while having fairly positive impacts on the trade balance. However, variance decompositions of trade balance show that exchange rate itself can hardly explain much about the change in the trade balance. Lan Huong Hoang [13] applied a multivariate Structural Vector Autoregressive (SVAR) and Vector Error correction model (VECM) to analyze short-term and long-term effects of foreign exchange rate on trade balance of Vietnam, using monthly data from 2004-2015. The real effective exchange rate is used to reflect the overall performance of Vietnam's currency. The results suggest that in short-term, the exchange rate has very limited impacts on trade flows; while in the longer horizon, it does not affect imports in either nominal or real terms but has a substantial effect on nominal exports. To the extent of this research, there are some policy implications has been made to support policymakers in Vietnam. Recently, Dang Thi Kim Dung [14] employs an unrestricted VAR model to examine determinants of the trade balance in Vietnam. Quarterly data set of three endogenous variables and one exogenous variable from January 1997 to December 2014 is used in this paper. Overall, she finds that trade balance in Vietnam is significantly negatively related to real domestic GDP per capita. A real depreciation of the real useful exchange rate index leads to an improvement of the trade balance. Notably, the empirical result shows that a real foreign GDP per capita hurts the trade balance. About FDI, the model indicates that FDI inflow has no impact to trade balance in overall in Vietnam.

Overall, the evidence suggests that there are different studies in the world as well as in Vietnam about the relationship between exchange rates and trade balance, the results related to the long-run and short-run relationships between the trade balance and its arguments are often dependent upon the theoretical approach, the observation period and the econometric technique employed. Therefore, to obtain robust results, the author utilizes the econometric methods -VAR/VECM estimation approach developed by Helmut [15] for this research's purposes.

\section{Materials and Methods}

\subsection{Data Gathering Procedures}

This research uses the secondary data which got from official world organizations as well as from official sources in Vietnam. The author proceeds by describing the estimated period, data sources, potential problems associated with the data and the methodology used for determining the real effective exchange rate for this study.
Data are collected quarterly from 2000 quarter one to 2016 quarter four and calculated for period-average. The data are in the form of a logarithm (since log-transformed data is normally distributed, it produces a better result than the In-transformed data). The REER and CPI are normalized to 100 in the year 2000 quarter 1 . In this research, I choose the period from 2000 to 2016 because the year 2000 is the time Vietnam has been taking actions to liberate the foreign exchange market since 1999. The liberation movement starting with Resolution No. $65 / 1999 /$ QĐ-NHNN7 of SBV which is highly essential as it is the indispensable prerequisite for economic laws to be applied in any econometric model.

Data on the export, import value, as well as trade balance in Vietnam, are obtained from the General Statistic Office (GSO) and Vietnam Customs. Data of Vietnam's consumer price index (CPI) and bilateral VND/USD exchange rate are derived from Vietnamese sources such as the State bank of Vietnam (SBV) and the GSO and are used to cross-check with those obtained from the International monetary fund (IMF) or as additional sources to fill some missing observations in the relevant IMF data series. Data of FDI inflow are collected from the IMF and World Bank (WB), and data of Vietnam's GDP are collected from GSO and IMF. The exchange rates between the Vietnam Dong (VND) and a particular currency in the basket are calculated as cross rates, based on their prices with the U.S. dollar.

Table 1. Data source and Description

\begin{tabular}{|c|c|c|}
\hline Variable & Description & Source \\
\hline REER & $\begin{array}{c}\text { Real effective exchange rate } \\
\text { (index) }\end{array}$ & Calculation \\
\hline CPI & Consumer price index & GSO, SBV, IMF \\
\hline $\mathrm{X}$ & Export value (million USD) & GSO, Vietnam Customs \\
\hline $\mathrm{M}$ & Import value (million USD) & GSO, Vietnam Customs \\
\hline $\mathrm{X} / \mathrm{M}$ & Export-Import ratio & Calculation \\
\hline GDP & $\begin{array}{c}\text { Gross domestic product } \\
\text { (million USD) }\end{array}$ & IMF, GSO \\
\hline FDI & $\begin{array}{c}\text { Foreign direct investment } \\
\text { inflow (million USD) }\end{array}$ & WB, IMF \\
\hline
\end{tabular}

Source: Author's collection,

\subsection{Statistical Treatment}

Trade balance: This paper utilizes all $\mathrm{X} / \mathrm{M}$ ratios regarding goods, services and the trade balance in the analysis. The $\mathrm{X} / \mathrm{M}$ ratio has been widely used as trade balance proxy in many empirical investigations of the trade balance and exchange rate relationship. This way one can perform nominal and real trade balance analysis without additional data manipulation. Also, it neatly solves the problem of using the log-form of a trade deficit. Increase in trade balance ratio means trade balance is improved. It has also been mathematically proved that the percentage change in trade balance ratio is approximately equal to the percentage change in trade balance itself.

\section{Real effective exchange rate (REER)}

Data on the real effective exchange rate is calculated as follows: 


$$
R E E R=\sum_{i=1}^{n} \frac{e_{t}^{i}}{e_{\text {base }}^{i}} w_{t}^{i} \cdot \frac{P_{t}^{V N}}{P_{t}^{i}}
$$

In which:

$-e_{\text {base }}^{i}$ : nominal exchange rate of VND against i country`s currency in the base year.

$-e_{t}^{i}$ : nominal exchange rate of VND against i country's currency in $\mathrm{t}$ year.

- $P_{t}^{i}$ : price index of $i$ trading partner in $t$ year.

$-w_{t}^{i}$ : the commercial proportion of $\mathrm{i}$ trading partner in $\mathrm{t}$ year.

$-P_{t}^{V N}$ : Vietnam price index in $\mathrm{t}$ year.

Where:

$$
w_{t}^{i}=\frac{I_{i}^{t}+E_{i}^{t}}{\sum_{i=1}^{n}\left(I_{i}^{t}+E_{i}^{t}\right)}
$$

$-I_{i}^{t}$ is the import turn-over to Vietnam from the trading partner $i$ in $t$ year

- $E_{i}^{t}$ is the export turnover of Vietnam to the trading partner $i$ in $t$ year.

The exchange rate of VND against i trading partner's currency will be worked out by spot cross-rate. The commercial proportion of $\mathrm{i}$ trading partner $\left(W_{i}^{t}\right)$ is calculated by dividing the total export and import values of Vietnam against $i$ country at $t$ moment by the total export and import volume of Vietnam against 20 partners at $\mathrm{t}$ time. The research focuses on analyzing the relation among macroeconomics variables in Vietnam as a whole. However, in this research, I choose 20 significant economies (Euro area, Australia, Hongkong, Japan, Korean, Singapore, United State, China, Malaysia, Thailand, Belgium, France, Germany, Italy, Switzerland, England, Cambodia, India, Indonesia and Philippine) which account for the total about 86.5 percent of trading from 2000 to 2016 to calculate REER.

Table 2. The average share of the trade of 20 countries used in REER calculation

\begin{tabular}{|c|c|c|c|}
\hline China & United State & Japan & Korean \\
\hline $20.9 \%$ & $12.8 \%$ & $120 \%$ & $101 \%$ \\
\hline Euro area & Singapore & Thailand & Malaysia \\
\hline $6.3 \%$ & $6.1 \%$ & $4.6 \%$ & $3.7 \%$ \\
\hline Australia & Germany & Hongkong & Indonesia \\
\hline $3.2 \%$ & $3.2 \%$ & $2.7 \%$ & $2.2 \%$ \\
\hline India & England & Belgium & France \\
\hline $2.0 \%$ & $1.8 \%$ & $1.6 \%$ & $1.6 \%$ \\
\hline Italy & Philippine & Cambodia & Switzerland \\
\hline $1.5 \%$ & $1.3 \%$ & $1.3 \%$ & $1.1 \%$ \\
\hline
\end{tabular}

Source: Calculation from data of IMF and GSO.

\subsection{VAR Model}

VAR model is an econometric model used to capture the linear interdependencies among multiple time series. VAR models generalize the univariate autoregressive model (AR model) by allowing for more than one evolving variable. All variables in a VAR enter the model in the same way: each variable has an equation explaining its evolution based on its own lagged values, the lagged values of the other model variables, and an error term. VAR modeling does not require as much knowledge about the forces influencing a variable as do structural models with simultaneous equations: The only prior knowledge needed is a list of the variables which can be hypothesized to affect each other intertemporally [15].

\section{The process of VAR/VECM estimation as follows:}

- Check for stationary of all variables by Augmented Dickey-Fuller test; If all variables are stationary / the VAR is stable, the adequate model is a VAR in levels. In this case, we can use simple regression to check the relation between variables in the long run.

- If all the variables are stationary of order one but not cointegrated, the adequate model is a VAR in first differences (no level components included).

- If the vars are stationary of order one but cointegrated by using Johansen test, then use VECM analyze.

- Choose the optimal lag length of the model by using Akaike Information Criterion (AIC), Schwarz information Criterion (SC).

- Estimate VAR/VECM Model.

- Analyse the impulse response function and variance decomposition. It is investigated how trade balance responds to macroeconomic variable shocks through the impulse response function analysis. Besides, the variance decomposition analysis will be showed to find the share of variations in a given variable caused by different shocks.

Since the objectives of this paper are to evaluate the impacts of the exchange rate as well as some main other macroeconomic variables, such as consumer price index, FDI inflow, and output on the trade balance, the Vector Auto-Regressive approach is employed to test the responsiveness of the trade balance to the change in those macro-variables. The reduced form VAR is set up such that a variable linearly depends on its lags and also on other variables and their lags. We consider a five-variable model that consists of the following variables: Output (GDP); real effective exchange rate (REER); Ratio of export value and import value (XM), as a proxy of trade balance; Consumer price index (CPI) and Foreign direct investment inflow (FDI). They are all treated as endogenous variables in the models. The reduced form equation can be written as,

$$
Y_{t}=\Gamma_{0}+\sum_{i=1}^{n} B_{t} Y_{t-i}+u
$$

Where $Y_{t}$ is the 5 vector of variables [Ln(REER), Ln(GDP), Ln(XM), Ln(CPI), Ln(FDI)], which are explained in more detail in the next section. $B_{i}$ is coefficient matrices of size $5 \times 5, u_{t}$ is error-disturbance, and $\Gamma_{0}$ is the intercept.

\section{Results and Discussion}

To see whether the data are stationary or not before estimating the result, the author use the Augmented Dickey-Fuller (ADF) Unit root tests. The testing results from the Table 3 reveal that all variables except for LnFDI are not stationary at the level form (the probability value is 
greater than 0.05 ). Then, all of them are stationary in the first different form (the probability value is smaller than critical value 0.05 ), therefore, in estimation the autoregressive model we use the first different form of all variables to test the impulse response function and the variance decomposition in order to merely analyze the effects of change in each variable to other variables in percentage.

Table 3. Augmented Dickey-Fuller test statistic

\begin{tabular}{|c|c|c|c|}
\hline Variables & $\begin{array}{c}\text { P-value } \\
\text { (Level) }\end{array}$ & $\begin{array}{c}\text { P-value } \\
\text { (1 }^{\text {st }} \text { difference) }\end{array}$ & $\begin{array}{c}\text { P-value } \\
\text { critical }\end{array}$ \\
\hline LnREER & 0.1551 & 0.0000 & 0.05 \\
\hline LnCPI & 0.9260 & 0.0002 & 0.05 \\
\hline LnFDI & 0.0089 & 0.0011 & 0.05 \\
\hline LnGDP & 0.7376 & 0.0039 & 0.05 \\
\hline LnXM & 0.3346 & 0.0000 & 0.05 \\
\hline
\end{tabular}

In this research, Akaike Information Criteria (AIC) is also used to determine the number of lags of the endogenous variables in the model. The lower the value of AIC statistic, the better the model is. After comparison of AIC of each trial model with the different lag length I choose the model with the lag length of endogenous variables equal to 4, not only the AIC but also HQ, LR and PFE have the smallest value at 5\% level testing.

Because the variables are introduced into the model at the first different form, the new names of variables will be D(LNCPI), D(LNREER), D(LNFDI), D(LNGDP), $\mathrm{D}(\mathrm{LNXM})$. VAR stability test result is indicated in Table 4.

\section{Table 4. Testing for stability condition of VAR model}

Roots of Characteristic Polynomial

Endogenous variables: D(LNXM) D(LNFDI) D(LNGDP) D(LNREER) D(LNCPI)

Exogenous variables: $\mathrm{C}$

Lag specification: 12

Date: 12/28/17 Time: 06:22

\begin{tabular}{ll}
\hline Root & Modulus \\
\hline-0.889212 & 0.889212 \\
$-0.064655-0.798433 \mathrm{i}$ & 0.801047 \\
$-0.064655+0.798433 \mathrm{i}$ & 0.801047 \\
$0.558055-0.403250 \mathrm{i}$ & 0.688502 \\
$0.558055+0.403250 \mathrm{i}$ & 0.688502 \\
$-0.138920-0.536924 \mathrm{i}$ & 0.554604 \\
$-0.138920+0.536924 \mathrm{i}$ & 0.554604 \\
$-0.218509-0.385311 \mathrm{i}$ & 0.442957 \\
$-0.218509+0.385311 \mathrm{i}$ & 0.442957 \\
0.228143 & 0.228143
\end{tabular}

No root lies outside the unit circle.

VAR satisfies the stability condition.

The test shows that VAR satisfies the stability condition. And then, since the variables are stable at the first difference level, the author use Johansen testing to check whether cointegration relation exists between them or not. The testing results show that there is no cointegration relation between the variables at $5 \%$ significant level from both Trace test and Max-eigenvalue test (Table 5), so the VECM cannot be used for estimation, The research will continue with VAR model estimation in which variables are in first different level and optimal lag length is 4 .

Table 5. Johansen cointegration Testing

Date: 12/28/17 Time: 17:13

Sample (adjusted): 2001Q2 2016Q4

Included observations: 63 after adjustments

Trend assumption: Linear deterministic trend

Series: LNXM LNFDI LNGDP LNREER LNCPI

Lags interval (in first differences): 1 to 4

Unrestricted Cointegration Rank Test (Trace)

\begin{tabular}{lllll}
\hline \hline $\begin{array}{l}\text { Hypothesized } \\
\text { No. of CE(s) }\end{array}$ & Eigenvalue & Statistic & Critical Value & Prob. ${ }^{* *}$ \\
& & & & \\
\hline \hline None & 0.371170 & 65.97409 & 69.81889 & 0.0975 \\
At most 1 & 0.240490 & 36.74876 & 47.85613 & 0.3595 \\
At most 2 & 0.211695 & 19.41864 & 29.79707 & 0.4631 \\
At most 3 & 0.066742 & 4.432800 & 15.49471 & 0.8657 \\
At most 4 & 0.001288 & 0.081189 & 3.841466 & 0.7757
\end{tabular}

Trace test indicates no cointegration at the 0.05 level

* denotes rejection of the hypothesis at the 0.05 level

**MacKinnon-Haug-Michelis (1999) p-values

Unrestricted Cointegration Rank Test (Maximum Eigenvalue)

\begin{tabular}{lllll}
\hline $\begin{array}{l}\text { Hypothesized } \\
\text { No. of CE(s) }\end{array}$ & Eigenvalue & $\begin{array}{l}\text { Max-Eigen } \\
\text { Statistic }\end{array}$ & $\begin{array}{l}0.05 \\
\text { Critical Value }\end{array}$ & Prob. ** \\
\hline None & 0.371170 & 29.22533 & 33.87687 & 0.1625 \\
At most 1 & 0.240490 & 17.33012 & 27.58434 & 0.5517 \\
At most 2 & 0.211695 & 14.98584 & 21.13162 & 0.2899 \\
At most 3 & 0.066742 & 4.351611 & 14.26460 & 0.8205 \\
At most 4 & 0.001288 & 0.081189 & 3.841466 & 0.7757 \\
\hline
\end{tabular}

Max-eigenvalue test indicates no cointegration at the 0.05 level

* denotes rejection of the hypothesis at the 0.05 level

**MacKinnon-Haug-Michelis (1999) p-values

The results of VAR estimation show that there are many lags of the same variables, each estimated coefficient is not statistically significant, possibly because of multicollinearity. However, collectively, they are all significant by the standard $\mathrm{F}$ test. According to the critical value of $F$ statistic at the significant level of 5 percent $\left(\mathrm{F}_{\alpha}\right.$ $(\mathrm{k}-1, \mathrm{n}-\mathrm{k}) \approx 1.9$ ) ( $\mathrm{k}$ is some variables and $\mathrm{n}$ is the number of observations), then all values of $F$ statistics are higher than the critical $F$ values. Thus, equations are statistically significant. Moreover, the benefits of $\mathrm{R}$ square in these equations are very high, it is over 81 percent for model of $\mathrm{D}(\ln \mathrm{XM})$, more than 58 percent for model of $\mathrm{D}(\mathrm{LnFDI})$, about 90.7 percent for model of $\mathrm{D}(\mathrm{LnGDP}), 28.5$ percent for model of $\mathrm{D}$ (LnREER) and 69.9 percent for model of $\mathrm{D}$ (LnCPI). Therefore, the estimation equations with four lags here are quite suitable for analysis.

By using ordinary least squares method (OLS), the results of the regression model for the import-export ratio are presented as follows: 


$$
\begin{aligned}
& D(L N X M) \\
& =-0.295 * D(\operatorname{LNXM}(-1))+0.025 * D(\operatorname{LNXM}(-2)) \\
& -0.232 * D(\operatorname{LNXM}(-3))-0.053 * D(\operatorname{LNXM}(-4)) \\
& +0.007 * D(\operatorname{LNFDI}(-1))+0.007 * D(\operatorname{LNFDI}(-2)) \\
& +0.006 * D(\operatorname{LNFDI}(-3))-0.009 * D(\operatorname{LNFDI}(-4)) \\
& -0.070 * D(\operatorname{LNGDP}(-1))-0.071 * D(\operatorname{LNGDP}(-2)) \\
& +0.011 * D(\operatorname{LNGDP}(-3))-0.098 * D(\operatorname{LNGDP}(-4)) \\
& -0.152 * D(\operatorname{LNREER}(-1))-0.178^{*} D(\operatorname{LNREER}(-2)) \\
& +0.008 * D(\operatorname{LNREER}(-3))-\mathbf{0 . 3 6 2} * D(\operatorname{LNREER}(-4)) \\
& -0.381 * D(\operatorname{LNCPI}(-1))+2.554 * D(\operatorname{LNCPI}(-2)) \\
& -0.383 * D(\operatorname{LNCPI}(-3))-0.110 * D(\operatorname{LNCPI}(-4))-0.029 \text {. }
\end{aligned}
$$

The result shows that the export over import ratio was significantly affected by the change in real effective exchange rate four periods before $(t$ statistic value $=$ $2.8967>t$ critical value) and the ratio of export over import itself one period before ( $t$ statistic value $=-2.01$, $t$ absolute value higher than $t$ significant value). According to the result, if the real effective exchange rate increase 1 percent ( 1 percent devaluation in Vietnam Dong against foreign currency), the export-import ratio in the fourth study period will decrease by 0.36 percent on average. Thus, the depreciation of the VND has not improved the rate of export over import in the short run; even currency devaluation has made the trade balance decrease in the short term, which may be caused by policy time lag.

To test the causality relationship between REER and $\mathrm{XM}$, the author use the Granger Causality testing with the following results following:
Table 6. The Granger Causality Testing

VAR Granger Causality/Block Exogeneity Wald Tests Date: 12/28/17 Time: 07:10

Sample: 2000Q1 2016Q4

Included observations: 63

\begin{tabular}{lcll}
\hline Dependent variable: & D(LNXM) & & \\
\hline Excluded & Chi-sq & Df & Prob. \\
\hline D(LNFDI) & 1.125602 & 4 & 0.8902 \\
D(LNGDP) & 8.906809 & 4 & 0.0635 \\
D(LNREER) & 13.18184 & 4 & 0.0104 \\
D(LNCPI) & 8.757317 & 4 & 0.0675 \\
\hline All & 36.24911 & 16 & 0.0027 \\
\hline
\end{tabular}

The results show that only the exchange rate effects on trade balance the significant level of 5\% (P-value $=0.0104$ $<0.05)$. It clears that the change of REER is a cause of Vietnam's export-import value fluctuation during the period of study. Consequently, the author continues to test the impulse response function and variance decomposition to examine the changes of macroeconomic variables to the shock of each variable.

\subsection{Analysis of Impulse Response Function Results}

The impulse responses to the related variables are estimated over a period of ten quarters horizon. In this test, the author lets the error term in real active exchange rate equation shocks (increases) by a value of one standard deviation and then see such a shock or change will change that variable itself and other variables in the current as well as future periods. The Responses of the trade balance to a positive real effective exchange rate shock is provided in the first graph of Figure 1.

Response to Cholesky One S.D. Innovations \pm 2 S.E.
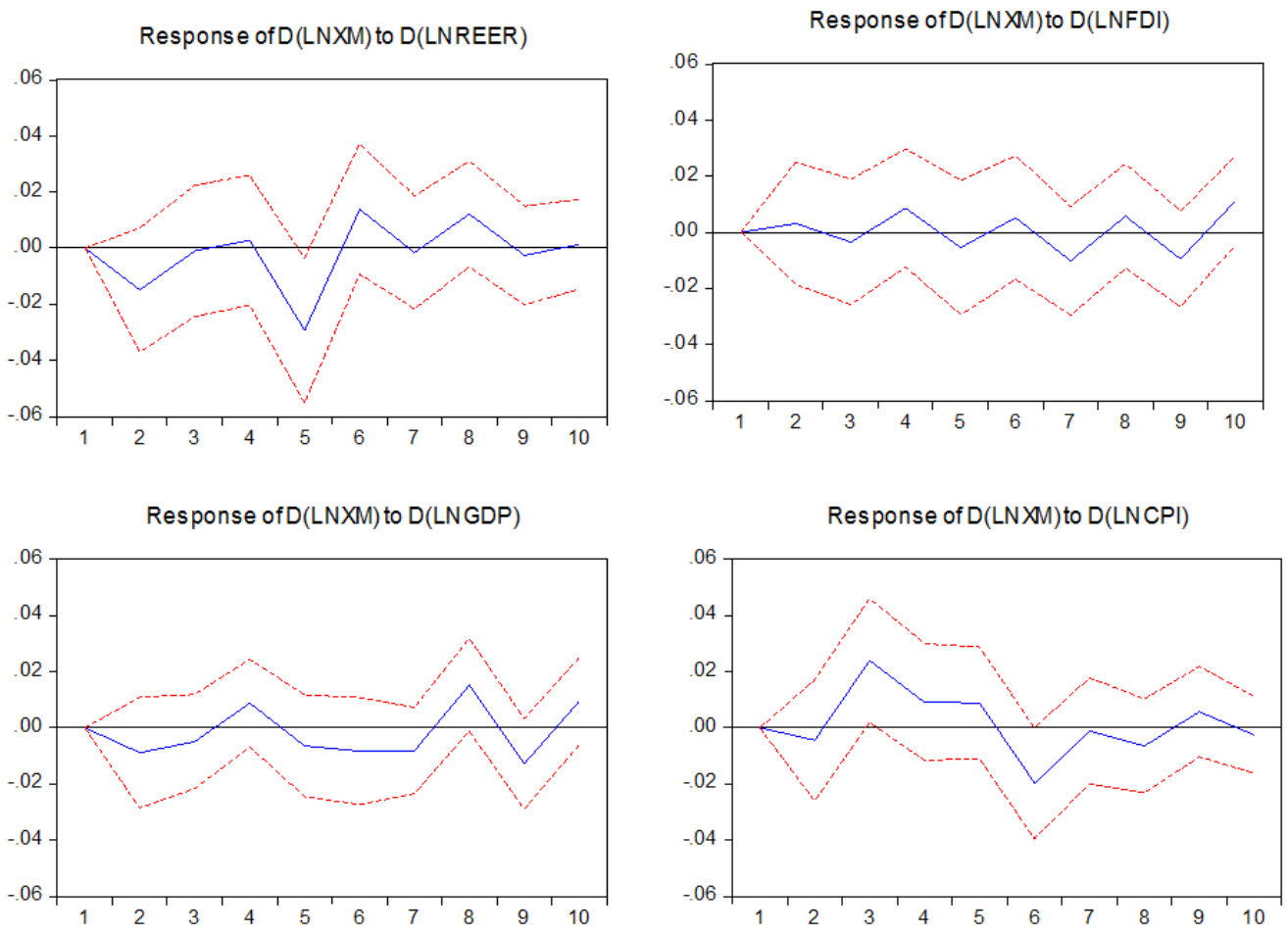

Figure 1. Responses of trade balance to other variable's change 
The result shows that in response to one standard deviation in the log of the real effective exchange rate, the trade balance turns to decrease slightly in the first and goes up in the second period but still negative then it becomes sharply increase and positive until the fourth period. The balance of trade does not improve in some first periods may be caused by the time delaying effects in both the consumption and production behavior. On the other hand, it also is explained that the export rises in response to the depreciation while the import increases by a much more significant amount then. But, the impact of trade balance increases by currency devaluation showed clearly in the graph from the fifth and became surplus from the sixth to the ninth period of the quarter in the impulse response function is considerable. This is an evidence of the "J" curve effect. Although Vietnam is a developing country, this finding is in line with the conclusion of Krugman, Obstfeld, and Melitz [10], in which they said that for most industrial nations, the $\mathrm{J}$ curve lasts longer than six months but less than a year. Moreover, this result, together with Petrović and Gligoric [16], positively contributes to the literature in the sense that the $J$ curve effect exists in emerging countries, where the exchange rate policy is considered to be unmanaged. However, our results contrary to Yuen-Ling, Wai-Mun, and Geoi-Mei [17], which showed no evidence of the J curve effect for Malaysia. One possible reason for this difference is that the impulse response functions generated from the VAR are not robust because of problems with standard errors. This finding of the research also supports for the results from the study of Lan Huong Hoang [13] in which she said that in short-term, the exchange rate has very limited impacts on trade flows; while in the longer horizon, it improved the trade balance because it had a substantial effects on nominal exports. The research of Dang Thi Kim Dung [14] also showed that a real depreciation of the actual useful exchange rate index leads to an improvement of the trade balance. However, she did not make clear the relationship between real effective exchange rate and the trade balance in the long or short term.

However, our results show that the $\mathrm{J}$ curve effect for the trade balance of Vietnam is quite long. It takes nearly six quarters for the balance of trade recovering after the devaluation of the domestic currency. This implies that price effect is dominant for quantitative efficiency, and two main reasons can explain it. Firstly, Vietnam's export capacity is quite limited due to limited equity. Also, most of the exports are agricultural products, or processed goods from agricultural products, mostly dependent on crops and climate change. Therefore, exporters can not quickly adjust to take advantage of the depreciation of the domestic currency. Secondly, import demand of the Vietnamese economy is high and continuous. Vietnam is a developing country and is in the process of industrializing the economy, while its domestic production is immature and can not meet the demand for high-tech products needed for industrial processes. As a consequence, the depreciation of the local currency has led to an increase in the price of imported goods in the domestic money, which also causes a rise in the total import value.

The fact of current account deficit in Vietnam in recent years may be explained that although devaluation policy has caused significant improvement in the Vietnam exports, the amount of imports has been increasing even more due to growing demand for inputs in domestic industries as well as higher national income. Also, Vietnam economy has not been capable of internal inputs based production; hence difficulties deriving from trade deficit will directly affect the national economy. Therefore, using devaluation instrument to encourage exports and improve the current account balance should be consistent with the solution for domestic capability in import substitution policy.

This fluctuation of the export over import ratio reflects the unclear relationship between REER and trading over import ratio in the short run. The long-term volatility of the exchange rate has created a positive but noncontinuous effect on export over import, which again confirms that the relationship is not apparent in the short term that is similar to the cointegration test above.

\subsection{Analysis Variance Decomposition of Results}

To find the share of variation in a given variable caused by different shocks, the variance decomposition from the VAR system is applied. The forecast error variance decomposition of LnXM is displayed in Table 7. In this variance Decomposition forecast, the author takes ten quarters ahead that help readers to see the fluctuation of the trade balance in log form both in short run and long run.

Table 7 shows that, in the short run that is quarter three, for example, the shock and XM can cause 85.85 percent fluctuation in XM (own shock), shock in FDI can cause 0.33 percent fluctuation in XM, shock or impulse in GDP can cause 1.53 percent change in XM, shock or impulse in REER can cause 3.36 percent change in XM and impulse in CPI can cause 8.9 percent change in XM. Thus, we can see that in the short run the impact of trade balance itself in previous has the most substantial effect on the fluctuation of the trade balance in the future, next is consumer price index shock and then is exchange rate shock, the least impact is from the foreign direct investment.

In the long run, at quarter ten, 66.84 percent the shock of XM cause fluctuation in XM (own shock), shock of exchange rate contributes 12.61 percent fluctuation in trade balance, impulse or shock in CPI cause 10.76 percent change in XM, impulse in GDP cause 7.36 percent change in XM and impulse in FDI cause 4.42 percent change in XM. The total impact of all variables causes 100 percent change in the trade balance in the analysis.

We can also see that in the short run, XM itself contributes 85.84 percent fluctuation in XM but in the long term, it contributes only 66.84 percent that means the impact of XM on XM itself goes down. However, for real effective exchange rate the contribution on $\mathrm{XM}$ fluctuation increases that is only 3.36 percent contribution in the short run to 12.61 percent contribution in the long term. Also, the contribution of the exchange rate that causes a fluctuation, in the long run, is the most significant amount except for trade balance itself, the highest percentage of contribution from REER is in quarter 8 , with 13.17 percent. It is no doubt that exchange 
rate plays a vital role in contributing trade balance trade in the long run. Besides, we can see that the shock in CPI causes the change in XM at the second level, although in the short term it contributes in XM more than REER, in a long time, it becomes the second factor that affects on trade balance fluctuation. The factor that least effect on trade balance both in the long run and short run is FDI, no more than 4.6 percent in ten quarters forecasting.

From VAR model, we can also see the Variance Decomposition tables of other variables such as LnGDP, LnFDI, LnREER, and LnCPI, however, in this study, the author only concentrates on the fluctuation of trade balance and impulse from others caused a change in the trade balance.

Table 7. Variance Decomposition of D(LNXM)

\begin{tabular}{|c|c|c|c|c|c|c|}
\hline & & & & & & \\
\hline 1 & 0.074 & 100.0000 & 0.000000 & 0.000000 & 0.000000 & 0.0000 \\
\hline 2 & 0.077 & 94.53 & 0.162 & 1.29 & 691 & .0249 \\
\hline 3 & 0.081 & 85.84689 & 0.330484 & 1.534099 & & \\
\hline 4 & 0.089 & 85.36933 & 1.187595 & & & 0.5702 \\
\hline 5 & 0.095 & 76.11140 & 1.372385 & 2.397 & 11.88289 & 8.2358 \\
\hline 6 & 0.099 & 71.18317 & 1.536290 & 2.901943 & 12.87509 & 11.5035 \\
\hline 7 & 0.102 & 70.75779 & 2.468494 & 3.411671 & & 11.019 \\
\hline 8 & 0.104 & 67.78982 & 2.6709 & 5.421 & & 10.942 \\
\hline 9 & 0.105 & 66.06096 & 3.404637 & 6.732683 & 12.86935 & 10.932 \\
\hline 10 & 0.100 & 64.84195 & 4128411 & 7.363486 & 12.00791 & 10.170 \\
\hline
\end{tabular}

In this study, the lag length of the model is 4, which means that changes in the factors in the model during this period will affect until the next four periods (quarters). This is also a primary problem of Vietnam macro policies, which work after an inevitable lag. The monetary policy implemented today; it can be useful for the economy after a specified period. This is also a basis of the empirical results to study recommendations for managing and operating exchange rate policy in the coming time.

\subsection{Policy Recommendations for Enhancement of Vietnam's Trade Balance}

\subsubsection{Experiences from Some Countries in the World in Term of Exchange Rate Policies to Improve the Trade Balance and Lessons Learned for Vietnam}

\section{Japan's exchange rate policy}

From a postwar economy, in the mid-1980s, Japan's economy rose steadily and joined the world's powerful countries at that time (including the United States, West Germany and the United States and Japan). The key to the miracle is export-led growth. One of the most important policies is the "Depreciate Japanese Yen." Maintaining a weak Yen against the US dollar for several decades had helped to boost Japan's competitiveness over developed economies in Western Europe and North America. As a result, during the 1970s and the first half of the 1980s, Japan defeated almost all economic rivals in any field that Japan chose as a battlefield [18].
The exchange rate policy that the Japanese government is adopting was a policy aimed at maintaining a low-value Yen against the US dollar, which had been consistently applied by the government for more than 20 years and became the most important factor which helped the Japanese economy successfully implement the export growth model. On September 22, 1985, five financial powers - the United States, France, Britain, Germany, and Japan - met in search of a solution to stop Japan's exponential increase in trade surplus and the corresponding trade deficit of the US. The answer chosen was the sharp devaluation of the dollar, appreciation of other currencies that targeted the Japanese Yen. Under the pressure of the United States and European partners, Japan forced to accept appreciating the Yen value [18].

Although the appreciation of the yen had a substantial impact on the export sector, threatening economic growth in Japan. But also thanks to the exchange rate changes, Japan, Japanese companies and the Japanese had become wealthy suddenly thanks to the appreciation of the yen. (The yen strengthened against the US dollar, then the Japanese bought much of it, they traveled and consumed more). Besides, after more than two decades of high-speed growth, Japan has accumulated a vast amount of financial assets. The volume of that asset was converted from the yen to the dollar and the "exchange rate" was doubled in just two years. This is indeed a miracle step that turns Japan into a financial powerhouse of conditionality as well as the forced change of growth model. From a commodity-only perspective, after the Plaza pledge, Japan's growth model relied more heavily on domestic demand. In that model, Japan appeared a new growth pillar: export and investment.

In short, the Japanese economy has had a tremendous breakthrough from an incident-solution: currency appreciation. The fact is that through the change in exchange rate policy, the Japanese economy has changed both a growth model, globalization with both trade and investment - in a rhythmic way. Before Japan, no country has done so consciously and effectively.

\section{China's exchange rate policy}

After implementing a comprehensive reform of the economy in 1978, China also established a foreign exchange control policy, the Chinese Yuan (CNY) was freely convertible into a current account and transferred part of the capital account. In line with the reform and transition of the economy, China's exchange rate regimes and policies have also been transformed to meet the requirements of a market economy with intervention from the socialist system. After about 40 years of innovation, China's economy has made remarkable achievements such as the highest economic growth rate, output of many leading products in the world. According to the IMF, China is a country with stringent exchange rate control policies and put restrictions on the issuance of money. Thus, China's real exchange rate policy is heavily influenced by nominal exchange rate control in the direction of CNY depreciation to enhance the international trade competitiveness and promote exports in term of price. Considered to be the "lever" of the world economy, China has run its exchange rate policy (in the direction of 
currency devaluation) which achieved some of the world's recognized success.

Under the impact of the Asian financial crisis of 1997, the international economic environment experienced considerable fluctuations. Many countries fell into recession and their living standards considerably reduced. This crisis slowed down economic growth and global trade. China was no exception when exports and foreign investment plummeted. Facing this situation, the Chinese government had a policy of not dumping the CNY, the exchange rate remained at $8.3 \mathrm{CNY} / \mathrm{USD}$, with small fluctuations. As a result, the impact of the Asian financial crisis on the Chinese economy was less severe.

To protect the CNY against the effects of the regional financial crisis in 1998, China returned to the tight control of the foreign exchange market, reduced the risk of speculation and hoarding of foreign currencies, increased foreign currency reserves. In parallel with the tightening of the foreign exchange market, to ease the pressure on exports and the growth of the economy, China also coordinated with economic policies such as easing monetary policy. With such a tight management regime, the exchange rate between the CNY and the US dollar was kept almost unchanged at CNY 8.3 per dollar until 2005. According to the leading economists, the CNY exchange rate had been underestimated by 30 percent against other currencies. Their low exchange rates created unfair trade advantages for Chinese goods in the international market, undermining the competitiveness of other exporters. Along with the benefits of resources and workforce, the maintenance of exchange rate imbalances between $\mathrm{CNY}$ and USD while the dollar was falling relative to other currencies helped Chinese exporters to take advantages of the price war with their trading partners during this period.

On July 21, 2005, China continued to introduce a new monetary policy, ending the application of a nominal exchange rate unchanged during nearly ten years. Accordingly, the transition to the new exchange rate mechanism brought about three significant changes. Firstly, the CNY value would be referenced with a basket of other currencies according to the supply and demand rules of the market. Secondly, the official exchange rate was down CNY 8,11 per USD with a daily fluctuation of $0.3 \%$. Thirdly, the fixed exchange rate regime was replaced by a controlled floating exchange rate regime. In May 2007, China's central bank adjusted its CNY daily fluctuation margin by $0.5 \%$. These innovations increased the flexibility for exchange rates. At the end of 2008, one dollar was worth only $6.83 \mathrm{CNY}$.

The global financial crisis of 2008 caused a stir in the world. In that situation, the Chinese government had limited the range of $\mathrm{CNY}$ fluctuations and kept at CNY 6.84 per US dollar for two years, while returning to the CNY in USD terms. On 16/4/2012, the fluctuation band of CNY against USD was widened to $1 \%$ per day. The controversial issue, however, is that China has consistently maintained a low exchange rate policy to increase the demand for commodities of other countries and to gain dominance in export activities. As China's share of the world's stock of global trade is low, the devaluation of the CNY has led to an imbalance in the worldwide business. For the three days from August 11-13, 2015, the Central Bank of China (BOC) continuously lowered the CNY, before rebounded on August 14. This is the strongest devaluation ever since China established its modern foreign exchange control system in 1994. BOC explained that they devalue the CNY to reflect more closely on development in the market and insisted that they would not reduce prices continuously. At the same time, they wanted to empower the CNY, made it easier to fulfill its strategic objectives and strengthen its central role in the global economy [18].

\section{Thailand's exchange rate policy}

Thailand is a newly industrialized country, starting in 1960. In the 1970s, Thailand pursued an "export-oriented" policy in which ASEAN, the United States, Japan, and the EU were the primary export markets for Thailand. The industry and services have gradually played an essential role in the economy, and the part of agriculture has declined. Thailand is also a country in the region with specific achievements in import-export activities, with nearly two-thirds of GDP made up of exports. Thus, the real exchange rate policy to improve the competitiveness of domestic goods is of great importance to this country. Historically, Thailand's exchange rate regime was divided by the 1997-1998 financial crisis. Before this crisis, Thailand maintained a fixed exchange rate regime, after the crisis, the exchange rate regime was shifted to floating without a pre-announced floating rate (managed to float with no preannounced path for exchange rate), and Thailand's monetary policy shifted towards inflation targeting.

Since May 2000, the central bank of Thailand (BOT) has managed the exchange rate targeting inflation to overcome the shortcomings of exchange rate management under the monetary policy such as instability between money supply and economic growth, credit growth, potential risks to the financial sector. Target inflation plays a significant role in monetary policy so that the exchange rate adjusts flexibly, avoiding shocks to the economy. To implement this policy, the BOT established a Monetary Policy Committee (MPC) consisting of three senior BOT officials and four external experts. MPC's mission is to set monetary policy to stabilize prices and economic growth. Every year, the MPC proposes essential inflation expected for next year and this essential inflation is allowed to fluctuate between $0.5-3.5 \%$ depending on the actual situation. Periodically from 6-8 weeks, MPC will meet and review the internal and external factors to forecast inflation in the coming time. This model is applied from the experience of the US and Japan. Through inflation targeting, the BOT controls exchange rates by intervening in the foreign exchange market with instruments such as foreign exchange reserves, open market operations to prevent market volatility. Accordingly, the exchange rate is allowed to fluctuate in a band to develop the economy steadily and against the shocks. There is no specific rule for the exchange rate, the ultimate goal of the exchange rate is to achieve inflation targeting and economic development.

In a nutshell, Thailand's central bank's exchange rate administration is quite flexible, based on a variety of forecasting techniques and analytical, regulatory tools. At the same time, the Thai central bank is always considering the impact of exchange rate fluctuations on future inflation 
and output. The floating rate regime has brought about high efficiency for monetary policy, contributing to the recovery of economic growth of Thailand quickly.

\section{Korea's exchange rate policy}

Today, Korea has achieved economic achievements known all over the world. It was an extraordinary process that quickly helped revitalize the Korean economy, marking a turning point in the country's history. To have a Korean as it is today, the Korean government has adopted a series of measures to regulate the economy, with a focus on exports. The government has implemented export-oriented policies in two critical steps: to encourage and increase savings by raising interest rates and improving trade deficits by devaluing the domestic currency. Also, the Government of Korea has implemented some measures to support exports such as reducing export tax, financial support for export enterprises in a reasonable way, financial incentives for critical industries, adjust the flexible exchange rate regime. After a series of government policies, the results are very positive. South Korea has become one of the fastest growing economies in the world, with exports rising from $\$ 41$ million in 1960 to $\$ 1.048$ million in 1970.

During the 1997 financial crisis, South Korea's exchange rate policy was more flexible to overcome the aftermath of the crisis. The most mentioned and highlighted issue of the rapid collapse of the Korean economy is the overload of debt. At this time, Korea's external debt is about $\$ 110$ billion, of which about 80 billion (accounting for $70.2 \%$ ) are short-term loans. It seemed that the exchange rate policy was the cause of the financial crisis in Korea. But the manipulation of the exchange rate policy to create stability in the early 1990s and early 1996 led to the appreciation of the KRW, the KRW almost unchanged against the US dollar. It also increased against the real JPY. This has led many Korean investors to over-borrow foreign capital, causing an overload of debts, primarily foreign currency debt. In the wake of the crisis, the devaluation of the KRW against the pushed Korean companies into financial difficulties. However, it strongly supported exports, which rose to $21.3 \%$ in 1997 and $13.3 \%$ in 1998 , with an increase of $3.7 \%$ comparing to 1996 . In the period of financial reform and economic change, Korea has quickly escaped the crisis and quickly restored its economy.

\section{Lessons learned for Vietnam}

The lessons learned from the exchange rate policy in Japan, China, Thailand, and Korea during the economic development process can be summarized as follows: Firstly, the exchange rate policy must be in line with the economic development strategy in each period to improve the competitiveness of the economy. Exchange rate policies should best support exports, investments, increase foreign exchange reserves, improve the balance of payments and create a precondition for sustainable economic development. Secondly, there should be a combination of ministries and agencies in administering the exchange rate policy to implement the macroeconomic objectives of the Government, especially between the central bank and the finance ministry, monetary policy and fiscal policy. The MPC model of Thailand can also be learned in the process of managing monetary and exchange rate policies.

Thirdly, to avoid external shocks, countries should anchor the local currency to a basket of foreign currencies. Experiences from the Asian financial crisis show that one of the causes of the crisis was that countries in the region anchored the currency exchange rate against the only foreign currency denominated in US dollars. This stability is only temporary and has a positive impact on investor sentiment. Investors believe in currency stability and the economy as the dollar devalues. However, as the dollar strengthens, it weakens the competitiveness of countries with currencies that are tied to the dollar. Experience from the 1997 financial crisis in Thailand is a prime example. After the crisis, Thailand has been running a more flexible exchange rate and has obtained positive results in economic development. Fourthly, It is the right time to choose the currency deviation. The appropriate exchange rate policy encourages exporters, contributes to the accumulation of capital to domestic industries. However, flexible exchange rate policy is a necessary condition that sufficient trade policies to boost export. Fifthly, currency devaluation needs to be combined with broadening exports at large scale. For a country that depends heavily on imports of machinery, materials, equipment and technology, as well as foreign borrowing to invest. Currency devaluation can reduce growth as a result of obstructing investment is greater than encouraging exports. However, Korea's wisdom is to expand exports at a large scale in combination with other factors that reduce import costs and debt burdens. In fact, after a sharp devaluation of the KRW, Korea has strengthened its production capacity and promoted trade promotion, thus achieving high export growth. Last but not least, the success of the exchange rate regime in this country is not synonymous with the success of that exchange rate regime in another country. Each exchange rate regime can bring great success to one or a group of countries, as in the case of Japan succeeding with weak yen for two decades and again with unprecedented success, but brought failure to some other countries. In the wake of currency devaluation, South Korea has taken appropriate measures to remove the possibility of prolonged depreciation of the local currency and then strengthen other market forces that keep rates unchanged. The stability of the KRW / USD exchange rate is due to the fact that the Korean government has maintained a stable fluctuation range over the long term. This really benefits domestic investors and attracts foreign investment. South Korea is one of the few countries to recover from the worst financial crisis in Southeast Asia and to implement its economic development strategy and to apply modern technology to improve its product quality.

\subsubsection{Policy Recommendations for Enhancement of the Vietnam's Trade Balance}

In Vietnam, in the last three decades, there has been a greater integration into the world economy. The authority has also pursued an export-led growth strategy with many supporting policies relating to trade, including exchange rate management. However, exchange rate tool seems not to be perfectly effective, therefore, it is necessary to combine the exchange rate policy and the other macroeconomic policies as well. 


\section{Moving to a flexible exchange rate}

According to the empirical study, the relationship between the exchange rate and the trade balance is weak in the short run, due to the exchange rate in Vietnam is tightly controlled by the SBV for a long time as well as Policies face time lag problem. Therefore, recommendations from the exchange rate policy may include reasons that are following: Firstly, our country is in the transition process; many industries must depend on imported raw materials, fluctuations in the exchange rate will affect the cost of business inputs, making it difficult for operations of enterprises. Secondly, the exchange rate is an essential variable in the economy, which affects inflation, the balance of international payments, GPB. Thirdly, the financial market of Vietnam is in its infancy, yet there haven't had enough hedging instruments of exchange rates. The forex market is underdeveloped and does not facilitate the relaxation rate. Fourthly, Vietnam's public debt is high (about 50\% of GDP). Thus, the currency devaluation would cause difficulties for the payment.

In fact, on January 4th, 2016, SBV officially changed to a center exchange rate. The regime, which considered the floating system. But according to some experts basically, the newly issued exchange rate regime is not new, because, in fact, the SBV is still the "key" in determining the central exchange rate and fluctuation band for the commercial banks is still at 3\%. Also, the new mechanism is not transparent. According to the SBV, the agency based on the basket of eight major foreign currencies to determine the mean rate but the methodology for calculation hasn't been announced. Besides, the macroeconomic, monetary balance as well as a difficult variable to determine. Therefore, investors have to observe the market and forecast the SBV's actions. If the SBV want the "new regime" to have a positive effect, there must be transparency of three factors mentioned above, a system to update statistical information and officially announce for the market to capture data and prevent risk proactively. In contrast, the non-transparent details of the macroeconomic stability needs, based solely on the SBV's goals, will cause instability, leading to unforeseen consequences in the future. However, in the context of global trade and investment situation, after the country has entered a series of FTAs, gradually floating exchange rate is a requirement. Moreover, the flexibility of the exchange rate policy can support the objective of maintaining the capacity of our country's goods in the international market. To do this, we need to promote the following activities:

Firstly, choosing the flexible exchange rate regime is only meaningful if the SBV can control the money supply to stabilize the domestic price level. Applying exchange rate flexibility will also make the economy face some risks, so the government should have risk-taking options related to the fluctuation of the exchange rate.

Secondly, moving to the floating exchange rate regime still requires intervention by the SBV in the foreign exchange market. The timing of the response mainly depends on the ability of the SBV to detect and analyze market indicators based on country experience and situation as well as on the SBV's assessment of such factors as exchange rate fluctuations, exchange rate fluctuations. The State Bank of Vietnam should implement appropriate interventions in a short period such as applying the exchange rate band in the transition to floating regime.

Thirdly, the SBV must increase transparency in the exchange rate policies. The SBV should define targets for intervening and announcing these objectives, disclosing information on foreign exchange reserves, changes in monetary policy, exchange rate policy; Announce the schedules of policymakers and their speeches.

Fourthly, the SBV must push the development of the forex market, interbank, and increase the link between these markets and derivative instruments. Applying the models for Vietnam should be studied by the experience of other countries to develop an appropriate roadmap and necessary adjustments in operation. Also, it is essential that the system of legal documents be amended to meet the market requirements and the surveillance systems be strengthened. The derivative instruments as futures, options, is the useful tool eliminates operational risks in export and import business.

\section{Coordination between exchange rate policy and other macro policies}

To improve the trade balance, Vietnamese policymakers may only be interested in exchange rate policies but also should coordinate with other macroeconomic policies; It is essential to maintain exchange rate stability promptly to avoid adverse impacts on the economy. The exchange rate policy must be combined with the following measures:

Firstly, to improve the trade balance, the most important is to enhance the competitiveness of export products by increasing quality and applying international standard and technical barriers and strengthen domestic production to replace imports gradually.

Secondly, the Government should implement many policies to support export such as encouraging investment, tax incentives, low-interest loans for businesses to establish and expand the business, focus on export support for essential products such as rice, rubber, coffee. Also, the government must work out solutions to protect its exports in the international market.

Thirdly, the development of supporting industries is essential. Policymakers should review policies, identify sources of funding and support (lending, guarantees, etc.), simplify procedures and records, and publicize policies. Incentives for supporting businesses.

Fourthly, the government should keep policies stable to attract more foreign investment. In recent years, significant exporters are phones and components, mainly from the considerable contribution of foreign direct investment enterprises. The most important thing is the phone, and phone parts with the participation of Samsung, LG, Microsoft, the unit has chosen Vietnam as the main production site in the world and the region, pulling hundreds of component suppliers, Helping export sales of commodity items increase more and more.

\section{Conclusion}

This research has analyzed the impact of the real effective exchange rate on the trade balance of Vietnam with quarterly data of the period of 2000 - 2016. The findings show that there exists a J-curve for Vietnam, the 
worsening effect on the trade balance due to a positive shock to the real effective exchange rate is strongest from the $4^{\text {th }}$ to the $6^{\text {th }}$ quarters. More importantly, the J-curve effect lasts about six quarters, which implies that the trade balance needs at least six quarters to improve after real depreciation of the domestic currency. Also, the result of Ganger causality testing also shows that real effective exchange rate is one of the cause that contribute trade balance fluctuation. From the results of variance decomposition, real effective exchange rate plays the most critical role in trade balance fluctuation since the $5^{\text {th }}$ quarter till the long run; consumer price index has the second impact on the trade balance, foreign direct investment and gross domestic products seem not to much effect on the trade balance.

From the findings and conclusion of the research, it suggests that exchange rate and trade balance relationship in Vietnam is still the critical concern for the economic researcher as well as macroeconomic policymakers. It shows that in the short run, devaluation of domestic currency does not improve the trade balance even it makes trade balance go to the deficit. The positive impact of trade balance caused by the depreciation of Vietnam Dong is seen in the long run. Besides, other factors like the gross domestic product and foreign direct investment seem not to affect on the trade balance fluctuation. Therefore, to get the surplus on the trade balance, policymakers should concern in the solution of a flexible exchange rate which only makes sense if SBV can control the money supply to stabilize the domestic price level. Moreover, moving to exchange rate flexibility with the floating regime still needs the intervention of the SBV in the foreign exchange market. The SBV must also increase transparency in exchange rate policy as well as promote the development of the forex market, interbank and strengthen linkages between these markets and derivative instruments. Besides, to improve the trade balance, Vietnam's policymakers can not only concern in exchange rate policy but also other macroeconomic systems as a whole. On the other hand, the government needs to implement more policies supporting exports, such as investment incentive, tax incentive, and offer solutions to protect the exporting products in the international market.

\section{References}

[1] Elif Guneren Genc and Oksana Kibritci Artar, "The effect of exchange rates on exports and imports of emerging countries", European Scientific Journal, Vol. 10, No. 13, 2014
[2] Tony Matlasedi, Richard Ilorah and Stephen Zhanje, "The impact of the real effective exchange rate on South Africa's trade balance", Economic Society of South Africa, University of Cape Town, 2 - 4 September 2015.

[3] Mohamed Nur Sharif and Ali Yassin Sheikh Ali, "Determinants of Trade Balance in Somalia: Regression Analysis using Time Series Data”, Journal of Economics and Sustainable Development, ISSN 2222-1700 (Paper) ISSN 2222-2855 (Online) Vol.7, No.12, 2016.

[4] Pham Hong Phuoc, "Real exchange rates and trade balance in Vietnam", 2009. [Online] Retrieved from: http://thuvien.due.udn.vn:8080/dspace/handle/TVDHKT.

[5] Nguyen Thi Hien, "Analysis of the balance of trade deficit of Vietnam at present period", Banking Journal, No. 24/2011.

[6] Dang Thi Huyen Anh, "The impact of real exchange rates on Vietnam's trade balance in international economic integration conditions", PhD thesis in Economics of Banking Academy, 2012, http://www.simpopdf.com.

[7] Nguyen Binh Duong, Tu Thuy Anh and Chu Thi Mai Phuong, "On the linkage between FDI and trade: Evidence from Vietnam", SECO/WTI Academic Cooperation Project, Working Paper Series $5 / 2012$.

[8] Nguyen Thi Tuyet Nga, 'The solutions for enhancing the role of exchange rates in the Vietnam economy's integration process", PhD Thesis of Banking University Hochiminh City, 2012.

[9] Hoang Khieu Van, "The effects of the real exchange rate on the trade balance: Is there a J-curve forVietnam? A VAR approach", MPRA Paper No. 54490, posted 19. March 2014 14:49 UTC.

[10] Krugman, P.R., Obstfeld, M., and Melitz, M.J., International Economics: Theory and Policy, Ninth Edition, 2012, pp.428-437 and p.447-449.

[11] Nguyen Nhat Mai, "Determinants of Trade Balance in Vietnam during the Period 1989-2013”, (June 15, 2015). Available at SSRN: https://ssrn.com/abstract=2926375.

[12] Nguyen Hai An, "Exchange Rate Management in Vietnam for Sustaining Stable and Long-Term Economic Growth", Review of Business and Economics Studies Volume 3, Number 2, 2015.

[13] Hoang Lan Huong, "The Role of Exchange Rate in Supporting Trade Balance in Vietnam", Working Paper No. HEIDWP16-2016.

[14] Dang Thi Kim Dung, "Research on Determinants of Trade Balance in Vietnam: a VAR Approach", Journal of Asean review of public affairs and policy, NO. 1 VOL. Three/ June 2017.

[15] Helmut Lutkepoh, "Econometric analysis with Vector Autoregressive Models", EUI Working Paper Eco 2007/11.

[16] Pavle Petrović and Mirjana Gligorić, "Exchange Rate and Trade Balance: J-curve Effect", PANOECONOMICUS, 2010, 1, pp. 23-41.

[17] Ng, Yuen. Ling., Har, W. M., and Tan, G. M., "Real exchange rate and trade balance relationship: An empirical study on Malaysia", International Journal of Business and Management, 3(8), pp. 130-137, 2008.

[18] Le Mai Trang, “Exchange rate policy for improving Vietnam's trade balance", Dissertation, Ha Noi Thuong Mai University, 2017. 